\title{
Effect of Current Ratio, Return on Equity, Debt to Equity Ratio, and Assets Growth on Dividends of Payout Ratio in Manufacturing Companies Listed in Indonesia Stock Exchange During 2014-2016
}

\author{
A. A. Ayu Erna Trisnadewi ${ }^{1, a}$, I Wayan Rupa ${ }^{1, b}$, Komang Adi Kurniawan Saputra ${ }^{1, c, \# ~ N i ~ N y o m a n ~ D i t a ~ M u t i a s a r i ~}{ }^{1, \mathrm{~d}}$ \\ ${ }^{1}$ Faculty of Economics and Business, Warmadewa University, Denpasar, Bali, Indonesia \\ e-mail: ${ }^{a}$ dewierna236@gmail.com; ${ }^{\text {b }}$ rupaiwayan2@gmail.com; ${ }^{\text {c\# }}$ komangadikurniawan@gmail.com; ${ }^{\text {d }}$ dita.mutia18@gmail.com; \\ ${ }^{\#}$ Corresponding Author \\ Whatsapp Number $\{+62-81944822418\}$
}

\section{ARTICLE HISTORY}

Received: 8 March 2019

Revised: 22 April 2019

Accepted: 17 June 2019

Copyright $\odot 2019$ Authors \& Published by IIES Independent. This is an open-access article distributed under the terms of the CC-BY-SA License.

\section{ABSTRACT}

This study aims to determine the effect of the current ratio, return on equity, debt to equity ratio, and assets growth on the dividend payout ratio in manufacturing companies listed on the Indonesia Stock Exchange during 2014-2016. The population in this study were 124 companies. The sampling technique used in this study was purposive sampling with a sample of 57 financial statements consisting of 19 companies. The data analysis technique used is multiple linear regression analysis using the SPSS program. The results showed that the current ratio did not affect the dividend payout ratio with a significance value of $0,246>0,05$. Return on equity has a positive effect on dividend payout ratio with a significance value of $0,030<0,05$ and a regression coefficient of 0,284 . Debt to equity ratio has a negative effect on dividend payout ratio with a significance value of $0,042<0,05$ and a regression coefficient of $-0,155$. Assets growth has a negative effect on dividend payout ratio with a significance value of 0,045 $<0,05$ and a regression coefficient of $-0,378$.

Keywords: Dividend Payout Ratio; Current Ratio; Return on Equity; Debt to Equity Ratio; and Assets Growth

How to Cite: Trisnadewi, A.A.A... Rupa, I.W., Saputra, K.A.K., \& Mutiasari, N. N. D (2019). Effect of Current Ratio, Return on Equity, Debt to Equity Ratio, and Assets Growth on Dividends of Payout Ratio in Manufacturing Companies Listed in Indonesia Stock Exchange During 2014-2016. International Journal of Advances in Social and Economics, 1(1), 1-5.

\section{Introduction}

The economic development of a country can be measured in various ways, one of which is to know the level of development of the capital market. According UU No.8/1995 about Capital Markets, the capital market has a strategic role in national development as a source of funding for the business world and investment vehicle for the public. Based on the results of a survey of one online media, it was seen that the number of people conducting stock investment activities through the Indonesia Stock Exchange (IDX) had increased.

Society thinks that the higher the profit of a company, the higher the dividend rate distributed to investors. Though companies that will distribute dividends are - faced with various kinds of considerations. For example in 2016 PT Unilever Indonesia Tbk (UNVR) decided to increase the number of dividends for the 2015 financial year, even though the profits obtained in 2015 decreased by $1.92 \%$ from the previous year. Another example is PT Gudang Garam Tbk (GGRM), where in 2018 PT Gudang Garam Tbk (GGRM) decided to distribute the 2017 financial year dividend the same as the previous year, even though the company was experiencing a slowdown.

Based on the above, it can be seen that the level of profit is not the only consideration of the company in distributing dividends. The financial ratio is one of the important factors that must be considered before 
making a decision to determine the amount of dividends to be paid to shareholders.

\section{Literature Review}

\section{Smoothing Theory}

Smoothing theory proposed by Lintner (1956). In his writing, Lintner expressed four opinions about dividend policy. First, the company has a target ratio of long-term dividend payments. Second, managers tend to emphasize changes in the size of profits rather than the absolute level. Third, in the long run, dividend changes that occur follow a stable movement pattern if the company's profits hold at a certain level. Fourth, managers are reluctant to make changes to dividends which will cause companies to reserve funds (Tatang, 2013: 51).

\section{Bird in Hand Theory}

According to this theory, dividends (termed birds in the hand) are preferred over retained earnings (birds in trees or in bushes). There are a number of important reasons and also empirical support for why high-risk companies must limit their dividends. This is because company profits that have high risk tend to be erratic, managers may still make low dividends to avoid a drastic decline if company profits decline sharply (Tatang, 2013: 52-53).

\section{Clientele Effect Theory}

Clientele effect theory explained that each company is owned by various types of investors. There is a group of shareholders who are in need of funds at that time. Generally they will expect a dividend distribution with a high ratio. There are also groups of shareholders who at that time did not really need their funds and preferred the company to withhold company profits for business expansion (Tatang, 2013:62).

\section{Dividend Signal Hypothesis Theory}

This theory was first put forward by Bhattacharya (1979). Based on this theory, dividend policy is considered as a signal for investors to assess the good and bad of the company. Companies that do not have a healthy financial condition indicate that the company has poor prospects going forward. However, in practice the amount of dividends distributed will affect the growth rate of the company (Tatang, 2013:63).

\section{Research Methods}

Place and object of the research
This research was conducted at manufacturing companies listed on the Indonesia Stock Exchange (IDX) for the 2014-2016 period. The object of this research is the current ratio, return on equity, debt to equity ratio, assets growth, and dividend payout ratio of the company.

\section{Population and sample determination method}

The population in this study were manufacturing companies listed on the Indonesia Stock Exchange (IDX) for the 2014-2016 period, totaling 124 companies. The method of determining the sample used in this study was purposive sampling, with the following criteria:

- Perusahaan a manufacturing companies listed on the Indonesia Stock Exchange (IDX) for the 2014-2016 period.

- Manufacturing companies that submit annual reports during 2014-2016 are consecutive and accessible.

- Manufacturing company that distributes dividends during 2014-2016.

\section{Operational Definition}

- Current ratio is the ability of manufacturing companies listed on the Indonesia Stock Exchange (IDX) to fulfill their short-term obligations using current assets owned by the company, which will be measured by comparing the current total assets with the company's total current debt.

- Return on equity is the ability of manufacturing companies listed on the Indonesia Stock Exchange (IDX) to generate profits based on equity owned, which will be measured by comparing the net income with equity held by the company in the same period.

- Debt to equity ratio is the ability of manufacturing companies listed on the Indonesia Stock Exchange (IDX) to cover part or all of their debt, both long-term and shortterm, with funds derived from total equity. The debt to equity ratio in this study is measured by comparing all debts with all company equity.

- Assets growth is the company's growth which can be seen from the growth in the number of assets owned. Assets growth in this study is measured by comparing changes in the 
number of assets with the amount of assets in the previous period.

- Dividend payout ratio is part of the income paid by manufacturing companies listed on the Indonesia Stock Exchange (IDX) as dividends to investors from 2014-2016. In this study, the dividend payout ratio can be measured by dividing dividends per share with net income per share.

\section{Data types and data sources}

The data used in this study are quantitative data, which is the data expressed in the form of numbers which are the results of calculations and measurements (Sugiyono, 2017: 7). The data sources in this study are secondary data in the form of annual financial statements of manufacturing companies listed on the Indonesia Stock Exchange (IDX) for the 2014-2016 period.

\section{Data Analysis Technique}

The data analysis technique used to solve the problem in this study is multiple linear regression analysis. Before the multiple linear regression analysis, the classic assumption test is carried out first which includes the normality test, heteroscedasticity test, multicollinearity test, and autocorrelation test. After the classic assumption test, a multiple linear regression analysis is conducted to determine the effect of the current ratio, return on equity, debt to equity ratio, and assets growth on the dividend payout ratio in manufacturing companies listed on the Indonesia Stock Exchange (IDX) for the 2014-2016 period.

\section{Data Analysis and Discussion}

\section{Classic assumption test}

The normality test in the study was carried out by the Kolmogorov-Smiarnov Test. Asymp.ig. (2-tailed) normality test results amounted to 0,082 greater than 0,05 , it can be concluded that the multiple regression data model is normally distributed.

The heteroscedasticity test in this study was carried out by the Glejser Test. The test results show that the significance value of all independent variables is greater than 0,05 , which means that there are no symptoms of heteroscedasticity in all independent variables.

The multicollinearity test shows the tolerance value for all variables greater than 0,10 and the VIF value is less than 10 , which means the regression equation model is free from the symptoms of multicollinearity. Watson Durbin value 1,763 is greater than the upper limit (dU) which is 1,7253 and smaller than (4-dU) which is 2,2747 so it can be concluded that there are no symptoms of autocorrelation.

\section{Multiple Linear Regression Analysis}

Table 1. Results of Multiple Linear Regression Analysis

\begin{tabular}{|c|c|c|c|c|c|c|}
\hline & \multirow{2}{*}{ Model } & \multicolumn{2}{|c|}{ Unstandardized Coefficients } & \multirow{2}{*}{$\frac{\text { Standardized Coefficients }}{\text { Beta }}$} & \multirow{2}{*}{$\mathrm{t}$} & \multirow{2}{*}{ Sig. } \\
\hline & & $\mathrm{B}$ & Std. Error & & & \\
\hline \multirow{5}{*}{1} & (Constant) & ,488 &, 100 & & 4,896 &, 000 \\
\hline & $\mathrm{X} 1$ & 021 & ,018 & ,174 & 1,172 & ,246 \\
\hline & $\mathrm{X} 2$ & ,284 &, 128 & ,292 & 2,227 & ,030 \\
\hline & $\mathrm{X} 3$ &,- 155 &, 075 &,- 336 & $-2,082$ & ,042 \\
\hline & $\mathrm{X} 4$ &,- 378 & ,184 &,- 244 & $-2,058$ & ,045 \\
\hline
\end{tabular}

a. Dependent Variable: Y

Based on table 1, the multiple linear regression equations that can be formed are as follows:

$\mathrm{Y}=0,488+0,021 \mathrm{X}_{1}+0,284 \mathrm{X}_{2}-0,155 \mathrm{X}_{3}-0,378 \mathrm{X}_{4}+$ e

The results of the multiple linear regression analysis above can be explained as follows:

F-test
Based on the results of the ANOVA test, the $\mathrm{F}$ value is 5.365 with a significance of $0,001 \mathrm{~b}<0,05$ so that it can be concluded that the current ratio, return on equity, debt to equity ratio, and asset growth together have a significant effect on the dividend payout ratio.

\section{T-test}

The results explain the effect of each independent variable individually on the dependent variable. 
1. The results of the analysis of the effect of the current ratio on the dividend payout ratio obtained a significance value of 0,246 greater than 0,05 , it can be concluded that the current ratio does not affect the dividend payout ratio.

2. The results of the analysis of the effect of return on equity on dividend payout ratio obtained a significance value of 0,030 smaller than 0,05 with a regression coefficient of 0,284 which means that there is a positive (unidirectional) effect between return on equity and dividend payout ratio.

3. The results of the analysis of the effect of the debt to equity ratio on the dividend payout ratio obtained a significance value of 0,042 smaller than 0,05 with a regression coefficient worth $-0,155$ which means there is a negative influence (opposite direction) between the debt to equity ratio and the dividend payout ratio.

4. The results of the analysis of the effect of assets growth on the dividend payout ratio obtained a significance value of 0,045 smaller than 0,05 with a regression coefficient worth $-0,378$ which means there is a negative influence (opposite direction) between assets growth and dividend payout ratio.

\section{Coefficient of Determination}

The results obtained by the amount of $\mathrm{R}$ Square of 0,161 this indicates that $16,1 \%$ dividend payout ratio can be explained by the current ratio variable, return on equity, debt to equity ratio, and asset growth, while $83,9 \%$ are determined or influenced by variables and other factors that were not detected in this study.

\section{Discussion}

- Based on the results of statistical tests, that the current ratio does not affect the dividend payout ratio, thus $\mathrm{H} 1$ in this study was rejected. Availability of raw materials is very important for manufacturing companies to carry out production activities, so companies must decide on a strategy in order to meet the needs of raw materials. One of the things that can be done by the company is through negotiations with many suppliers and then develop long-term partnership relationships with the suppliers concerned so that the company does not need to have a high ratio.

- Based on the results of statistical tests, return on equity has a positive effect on dividend payout ratio, thus $\mathrm{H} 2$ in this study was accepted. Return on equity is a benchmark for a company's ability to generate profits with its own capital used. The higher the profit obtained by the company, the higher the dividends paid tend to be the same as vithe same as vice versa.

- Debt to equity ratio has a negative effect on dividend payout ratio, this $\mathrm{H} 3$ in this study is accepted. Companies with a high debt to equity ratio tend to limit the level of dividends. This is because the net income obtained will be preferred to pay off the debt.

- Assets growth has a negative effect on dividend payout ratio, thus $\mathrm{H} 4$ in this study is accepted. Firms that are already established with stable profit rates tend to pay higher dividends. While companies that are in a period of growth have a dividend payout ratio that tends to be lower because the need for cash is quite high.

\section{Conclusion and Recommendation}

\section{Conclusion}

Based on the results of the analysis that has been done, it can be concluded that the current ratio does not affect the dividend payout ratio in manufacturing companies listed on the Indonesia Stock Exchange (IDX) for the 2014-2016 period. Return on equity has a positive effect on the dividend payout ratio in manufacturing companies listed on the Indonesia Stock Exchange (IDX) for the 2014-2016 period. While the debt to equity ratio and assets growth have a negative effect on the dividend payout ratio in manufacturing companies listed on the Indonesia Stock Exchange (IDX) for the 2014-2016 period.

\section{Recommendation}

Based on the research that has been done, the suggestion that can be proposed is that it is expected for companies that will distribute dividends and investors who want to invest in order to pay attention to the company's financial ratios, especially the level of profits earned, debt position, and company growth. In addition, it is expected that the next researcher can add years of observation so that they can provide better predictions.

\section{References}

Afriani, Fillya. Et al. (2015). Pengaruh Likuiditas, Leverage, Profitabilitas, Ukuran Perusahaan, dan Growth Terhadap Kebijakan Dividen. www.eprints.mdp.ac.id. (diakses pada 12 April 2018). 
Ghozali, Imam. (2018). Aplikasi Analisis Multivariate Dengan Program IBM SPSS 25 Edisi 9. Semarang: Universitas Diponegoro.

Gumanti, Ary Tatang. (2013). Kebijakan Dividen Teori, Empiris, dan Implikasi. Yogyakarta: UPP STIM YKPN.

Kasmir. (2017). Analisis Laporan Keuangan. Jakarta: PT Raja Grafindo Persada.

Kontan. (2016). Dividen UNVR Naik Meski Laba Turun. https://investasi.kontan.co.id (15 November 2018).

Martani, Dwi. Et al. (2017). Akuntansi Keuangan Menengah Berbasis PSAK. Jakarta: Salemba Empat.

Muhammadinah dan Mahmud. (2014). Pengaruh Current Ratio, Debt to Equity Ratio, Total Assets Turnover, dan Return on Assets Terhadap Dividend Payout Ratio Pada Perusahaan Sektor Industri Barang Konsumsi yang Terdaftar di Bursa Efek Indonesia. www.jurnal.radenfatah.ac.id. (diakses pada 25 Maret 2018).

Perpatih, Zuhafni. (2016). Pengaruh "ROA" dan "DER” Terhadap Dividend Payout Ratio (DPR) Pada Perusahaan Manufaktur Sektor Industri Dasar dan Kimia yang Terdaftar di Bursa Efek Indonesia. www.stie-yappas.ac.id. (diakses pada 25 Maret 2018).

Sari, Amilia dan Widhaningrat. (2014). Analisis Pengaruh Return on Equity, Earning per Share, Current Ratio, Quick Ratio, Current Earning, dan Growth Terhadap Dividend Payout RatioPerusahaan Manufaktur yang Terdaftar di Bursa Efek Indonesia Periode 2010-2013. www.lib.ui.ac.id. (diakses pada 12 April 2018).

Sari, Rencana dan Diota Prameswari. (2018). Investasi Pasar Modal Indonesia. Jakarta: PT Raja Grafindo Persada.

Sugiyono. (2017). Metode Penelitian Kuantitatif, Kualitatif, dan R\&D. Bandung: Alfabeta.

Utama, Suyana Made. 2016. Aplikasi Analisis Kuantitif. Denpasar: CV Sastra Utama.

Wahyuni, Ayu. (2015). Pengaruh Profitabilitas dan Likuiditas Terhadap Besarnya Dividen yang Dibagikan Kepada Pemegang Saham Pada Perusahaan Manufaktur yang Terdaftar di Bursa Efek Indonesia. https://ejournal.undiksha.ac.id. (diakses pada 25 Maret 2018).

Wasono dan Rina Cahyani. (2018). Industri Rokok Lesu Gudang Garam Bagi Dividen Rp 5 Trilliun. https://bisnis.tempo.co (diakses pada 15 November 2018). 